\title{
Guanidinium and phosphonium scaffolds loaded with silver nanoparticles: synthesis, characterization, in vitro assessment of the antibacterial potential and toxicity
}

M. N. Gorbunova ( $\square$ mngorb@yandex.ru )

Institute of Technical Chemistry

L.M. Lemkina

Institute of Ecology and Genetics of Microorganisms
A.l. Nechaev
Institute of Technical Chemistry

\section{Research Article}

Keywords: guanidinium salt, phosphonium salt, radical polymerization, silver nanocomposites, bactericides

Posted Date: February 13th, 2021

DOI: https://doi.org/10.21203/rs.3.rs-212281/v1

License: (c) (i) This work is licensed under a Creative Commons Attribution 4.0 International License. Read Full License

Version of Record: A version of this preprint was published at Journal of Inorganic and Organometallic Polymers and Materials on February 19th, 2021. See the published version at https://doi.org/10.1007/s10904-021-01941-2. 


\section{Abstract}

New silver nanocomposites based on polysulfones of 2,2-diallyl-1,1,3,3-tetraethylguanidiniumchloride [poly $\left(\mathrm{AGC}_{\mathrm{SO}}\right)$ ],

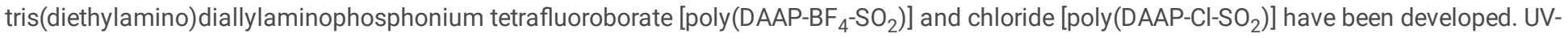
spectroscopy, SEM and XRD techniques were used to characterize the formation of silver nanoparticles in copolymers. Antibacterial action of new silver nanocomposites on S. epidermidis 33 and Escherichia coli (planktonic cells and biofilms) was studied. The silver nanocomposites strongly inhibited biofilms formation of S. epidermidis 33 and Escherichia coli. The silver nanocomposites based on phosphonium polysulfones have a significant cytotoxic activity against $R D$ and $M S$ line cells.

\section{Introduction}

Metal nanoparticles exhibit fascinating optical, catalytic, magnetic and biological properties [1-5]. The unique size- and shape-dependent properties of metal nanoparticles make them perspective in many fields of modern science and technology. Among metal nanomaterials, silver nanoparticles have attracted considerable attention.

The creation of nanomaterials from silver nanoparticles is the most promising, especially in connection with the recently discovered possibilities of an infinite variety of sizes, shape, composition and structure of nanoparticles obtained by chemical methods [6, 7]. Silver nanoparticles have the rare combination of valuable qualities: unique optical properties, high surface area, catalytic activity, high-capacity electric double layer [8]. Several comprehensive reviews are devoted to the study of antimicrobial and antiviral properties of silver compounds [9-12]. Unfortunately, as long as there are not so many ways to create materials from nanoparticles, since their aggregation leads to the loss of most of the unique characteristics $[7,13,14]$. To prevent aggregation, it is necessary to use stabilizing agents, such as self-assembled monolayers [15, 16], surfactants [17-19], polymers [20-23] or dendrimers [24, 25]. These stabilizers protect the nanoparticles from the environment and prevent their agglomeration, and moreover play an important role in controlling the size and shape of the particles.

The most widely used method is the application of polymers as stabilizing agents. N, P, S-containing high-molecular compounds with various functional groups are highly effective as polymer matrices that stabilize metal nanoparticles preventing their aggregation. The presence of various functional groups (amine, guanidinium, phosphonium, sulfo) in polysulfones provides great prospects for their use for stabilizing silver nanoparticles. Polyfunctional macromolecules can provide a favorable microenvironment for the reduction of silver ions due to the coordination binding of silver ions with the functional groups of copolymers [26]. Therefore, copolymers obtained by radical copolymerization of guanidinium and aminophosphonium salts with sulfur dioxide are promising for the development of stable metal-polymer nanocomposites.

Among biocide polymers, the polymeric quaternary ammonium, guanidinium or phosphonium salts have gained importance as medical, crop protection agents and antiseptics for industry products, foods, etc. [27-34]. They are believed to be effective in inhibiting the growth of bacteria. The combination of two biocide fragments (biocide polymer and silver nanoparticles) is relevant because makes it possible to purposefully enhance the antimicrobial properties characteristic of individual parts.

Nanotoxicity is critical to predicting potentially adverse effects of silver nanoparticles for sustainable development thereof in the future [35]. It can be assumed that polysulfones used as nano-stabilizing matrices will not only prevent particle aggregation, but also provide a prolonged biological effect, improve bioavailability, and, potentially, make it possible to correct the toxicity of nanoparticles.

In this work we report the synthesis of soluble silver nanocomposites (AgNCs) based on guanidinium and aminophosphonium polysulfones and their antimicrobial effect. We investigate the biocide action of these nanocomposites against Gram-positive and Gram-negative bacteria. Improving the effectiveness of treatment is impossible without testing biocides for their ability to penetrate biofilms, act on already formed communities and inhibit their formation and resettlement. Therefore, the ultimate goal was to study the effect of nanocomposites on biofilm formation and on developed (in $24 \mathrm{~h}$ ) biofilms of S. epidermidis 33 and Escherichia coli. In addition to antimicrobial activity, the toxicity of nanocomposites is also of paramount importance. To our knowledge, the antibacterial activity of silver/polysulfone nanocomposites and their toxicity has not been reported in the literature and this is the first report on the antibiotic effect of nanocomposites on S. epidermidis 33 and Escherichia coli biofilms.

\section{Materials And Methods}

\section{Materials}

2,2-Diallyl-1,1,3,3-tetraethylguanidiniumchloride (AGC) was synthesized from tetraethylurea as described in [36]. The yield of AGC was 70\% from the theory. $\left(\mathrm{C}_{15} \mathrm{H}_{30} \mathrm{CIN}_{3}\right)$ (287.5): Calcd. C 62.61, H 10.43, N 14.61; Found C 62.42, H 10.67, N 14.58. 
Tris(diethylamino)diallylaminophosphonium tetrafluoroborate $\left(\mathrm{DAAP}_{-} \mathrm{BF}_{4}\right)$ and chloride (DAAP-Cl) were obtained as described in [37]. The yield of DAAP-Cl was 86.5\%. $\left(\mathrm{C}_{18} \mathrm{H}_{40} \mathrm{CIN}_{4} \mathrm{P}\right)$ (378.5): Calcd. C 57.07, H 10.57, N 14.79.; Found C 56.82, H 11.06, N 14.55.

The yield of DAAP- $\mathrm{BF}_{4}$ was 70.1\%. $\left(\mathrm{C}_{18} \mathrm{H}_{40} \mathrm{~F}_{4} \mathrm{~N}_{4} \mathrm{~PB}\right)(430)$ : Calcd. C 50.23, H 9.30, N 13.02; Found C 49.72, H 10.03, N 12.83.

Chemical shift values and signals multiplets of the atoms $(\delta, \mathrm{ppm})$ of AGC, DAAP-Cl and DAAP- BF 4 are shown in Table $1 S$ in Supplementary data.

Sulfur dioxide was dried by passing through concentrated sulfuric acid and freshly-sintered $\mathrm{CaCl}_{2}$.

All the other chemicals were obtained from commercial suppliers. The characteristics of applied initiator (2,2'-azobisisobutyronitrile (AlBN)) and solvents (DMSO, methanol, tetrahydrofuran) conformed to the reference data after purification by conventional methods.

\section{Copolymerization}

The copolymerization experiments of AGC, DAAP-Cl and DAAP-BF 4 with $\mathrm{SO}_{2}$ were carried out in a glass reactor according to the following technique. A desired quantity of $\mathrm{SO}_{2}$ was introduced into a liquid nitrogen-cooled reactor via condensation, then the necessary quantity of allyl monomer, initiator AIBN $\left(3.0 \cdot 10^{-2} \mathrm{~mol} / \mathrm{L}\right)$ and solvent were added. The reactor was sealed and the reaction was carried out at the chosen temperature. Copolymers were precipitated and purified by three-fold reprecipitation by a precipitant from the solution. Solvent and precipitant for all systems were methanol and tetrahydrofuran respectively. The purified copolymers were dried under vacuum at $50{ }^{\circ} \mathrm{C}$ until constant weight was achieved. The copolymer composition was calculated from the elemental analysis data.

\section{Synthesis of AgNCs}

Synthesis of silver nanocomposites was conducted as follows. Poly $\left(\mathrm{AGC}-\mathrm{SO}_{2}\right)$ or poly(DAAP-Cl-SO $\left.{ }_{2}\right)\left(10^{-2} \mathrm{~mol}\right)$ were dissolved in water $(70 \mathrm{ml})$ and poly $\left(\mathrm{DAAP}_{-} \mathrm{BF}_{4}-\mathrm{SO}_{2}\right)\left(10^{-2} \mathrm{~mol}\right)$ was dissolved in methanol $(40 \mathrm{~mL})$. Then $\mathrm{AgNO}_{3}\left(10^{-3}-10^{-2}\right.$ mol of $1 \%$ aqueous solution) was added and the reactive mixture was stirred for one hour at room temperature. Then $\mathrm{NaBH}_{4}\left(2 \times 10^{-3}-2 \times 10^{-2}\right.$ mol) was added dropwise with the constant intensive stirring and the reactive solution was stirred for ten hours at room temperature. Nanocomposites were separated by dialysis. The purified AgNCs were dried under vacuum at $50{ }^{\circ} \mathrm{C}$ until constant weight was achieved.

\section{Measurements}

Fourier transform infrared spectra (FT-IR) were recorded using a Vertex 80v Bruker spectrometer at a resolution of $4 \mathrm{~cm}^{-1}$.

The ${ }^{1} \mathrm{H}$ and ${ }^{13} \mathrm{C}$ NMR spectra were recorded on a Bruker Avance II spectrometer operating at 400 and $100 \mathrm{MHz}$, respectively, using a broad-band proton decoupling and in a JMOD (J-modulated) mode. DMSO- $\mathrm{d}_{6}$ was used as a solvent; tetramethylsilane was used as an internal standard.

The molecular weight of copolymers was determined by the sedimentation method (methanol, $\left.25^{\circ} \mathrm{C},(30-40) \cdot 10^{3} \mathrm{circle} / \mathrm{min}\right)$.

The optical properties of the AgNCs were measured using a CF-2000 spectrophotometer in a wavelength range of 200-600 $\mathrm{nm}$.

The structure of produced nanocomposites was explored by X-ray phase analysis on the XRD-7000 diffractometer (Shimadzu, Japan) using the CuKa-radiations $(\mathrm{k}=1.54062 \mathrm{E})$ in angular interval $2 \theta=10-80^{\circ}$.

Concentration of $\mathrm{Ag}$ in aqueous solutions was determined with using of atomic-absorption spectrometer iCE 3500 («Thermo Fisher Scientific»,USA).

Samples of nanocomposites were studied by means of FEI QUANTA FEG 650 microscope (Netherlands).

The particle size was determined from the dynamic light scattering measurements using a ZetaPALS analyzer (Brookhaven, USA).

\section{Microbiological tests}

Microbiological tests were performed by serial two-fold dilution. Test cultures were Staphylococcus aureus, ATCC 25923; Staphylococcus epidermidis 33 GIS; Staphylococcus epidermidis, ATCC 29887; Micrococcus luteus, NCIMB 196; Escherichia coli, ATCC 25922; Bacillus subtilis ATCC 6633; Salmonella spp;; Pseudomonas aeruginosa, ATCC 27853. Bacterial strains used in the work were obtained from FSBI «Scientific Centre for Expert Evaluation of Medicinal Products» of the Ministry of Health of the Russian Federation (Moscow). Microbial loads were $10^{6}$ cells in $1 \mathrm{ml}$ in LB medium. Bacterial culture was put into 96-well polystyrene microtiter plate for $24 \mathrm{~h}$ at $37^{\circ} \mathrm{C}$. The concentration of planktonic cells was evaluated by measuring the optical density at $570 \mathrm{~nm}\left(\mathrm{OD}^{570}\right)$. The minimum bacteriostatic concentration (MBsC) was the lowest 
concentration of an antibacterial at which bacteria failed to grow. Duplicate sets of plates were prepared each time and each experiment was repeated three times to obtain accurate results.

\section{Biofilm formation}

Biofilm formation (S. epidermidis 33 and Escherichia coli) was analyzed as follows. Cells from fresh LA medium were inoculated into NB and incubated under shaking for $24 \mathrm{~h}$ at $37^{\circ} \mathrm{C}$. The cultures were then diluted 300 -fold in fresh NB supplemented with different AgNCs concentrations. Inoculated cultures were grown in 96-well polystyrene microtiter plates for $24 \mathrm{~h}$ at $37 \circ \mathrm{C}$ under a gentle shaking to prevent the formation of sediment at the bottoms of the wells. The growth of planktonic (unattached) cells was evaluated by measuring the optical density at $570 \mathrm{~nm}\left(\mathrm{OD}^{570}\right)$ of the cells suspension. We measured biofilm formation by discarding the medium, rinsing the wells with distilled water and staining the attached cells with gentian violet (1\%). After staining, the liquid was discarded and the wells were rinsed three times with distilled water. Then, the biofilm-associated gentian violet was solubilized with ethanol, and the absorbance at $570 \mathrm{~nm}\left(A^{570}\right)$ was measured.

A microplate reader (Benchmark Plus, Bio-Rad, USA) was used for measuring planktonic growth and biofilms. The bacterial growth for $24 \mathrm{~h}$ was found to be optimal at the plateau of the biofilm formation.

\section{Effect of AgNCs on the developed biofilms}

A culture (S. epidermidis 33 or Escherichia coli) was diluted 300-fold in NB, and thereafter the cells were grown on glass slides during $24 \mathrm{~h}$ at 37 -C forming the biofilms. The culture supernatant was removed and a fresh NB medium was added with different concentrations of AgNCs. Then, cells were further grown during $24 \mathrm{~h}$. Biofilms were analyzed by using gentian violet as described above.

\section{Acute toxicity}

Acute toxicity of AgNCs was measured in mongrel white male mice weighing 18-20 g, using intraperitoneal doses. The mice were injected with these nanocomposites. The dose was up to $1000 \mathrm{mg} / \mathrm{kg}$. The nanocomposites were dissolved in DMSO. Each group consisted of six animals. The animals were observed for 48 h. LD 50 values were calculated by Prozorovskiy's method [38].

\section{MTT tests}

Cytotoxicity of compounds was performed as follows. Cell lines of human lung carcinoma ( $A 549$ ), human rhabdomyosarcoma (RD TE32), human melanoma (MS) and human embryonic kidney (HEK293) were obtained from the N.N. Blokhin Cancer Research Center, Russian Academy of Medical Sciences (Moscow). Cells were kept in DMEM medium (for A549, RD and HEK293) and in RPMI 1640 medium (for MS) supplemented with $10 \%$ fetal bovine serum, $2 \mathrm{mM} \mathrm{L}$-glutamine and $1 \%$ gentamicin at $37^{\circ} \mathrm{C}$ in the Isotemp Barnstead $\mathrm{CO}_{2}$ incubator.

The $50 \%$ cell growth inhibitory concentration $\left(\mathrm{IC}_{50}\right)$ of the synthesized compounds was determined by the MTT method. $A 549, R D, M S$ and HEK293 cells were inoculated at $1.0 \times 10^{6}$ cells $/ \mathrm{mL}$ in 96 -well plates and incubated at $37^{\circ} \mathrm{C}$ in a humidified atmosphere with $5 \% \mathrm{CO}_{2}$. After $24 \mathrm{~h}$ incubation, various concentrations of the tested compounds $(100-1.56 \mu \mathrm{M})$ were added into each well, and these cells were incubated at $37^{\circ} \mathrm{C}$ in a humidified atmosphere with $5 \% \mathrm{CO}_{2}$ for $72 \mathrm{~h}$. All compounds were dissolved in DMSO. The final DMSO concentration in each well did not exceed $0.1 \%$ and was not toxic for the cells. The wells with a specific cell culture containing $0.1 \%$ DMSO solution in the medium were monitored as control. After incubation, $20 \mu \mathrm{M}$ MTT (3-(4,5-dimethylthiazol-2-yl)-2,5-diphenyl tetrazolium bromide), at a final concentration of $5 \mathrm{mg} / \mathrm{mL}$, was added into each well, and the cells were incubated for another $4 \mathrm{~h}$. The medium was removed and $60 \mu \mathrm{L}$ DMSO was added to each well. The optical density was measured at $544 \mathrm{~nm}$ using a FLUOstar Optima microplate reader. Concentrations $\left(\mathrm{IC}_{50}\right)$ were calculated according to the dose-dependent inhibition curves.

All experiments were performed for three times and the data were presented as means \pm standard deviation (SD). To test the significance of observed differences between the study groups, Student's t-test was applied. A value of $p<0.05$ was considered to be statistically significant.

\section{Results}

\section{Copolymerization}

The polysulfones based on 2,2-diallyl-1,1,3,3-tetraethylguanidiniumchloride, tris(diethylamino)diallylaminophosphonium tetrafluoroborate and chloride have been obtained by free radical polymerization according to the methods described in our publications [36, 37].

Copolymerization of guanidinium and diallylaminophosphonium salts with sulfur dioxide proceeds via complexation resulting in obtaining of alternating copolymers of equimolar composition independent on the monomer ratio in the initial mixture and reaction conditions.

The structure of the polysulfones obtained was investigated by ${ }^{13} \mathrm{C}$ NMR spectroscopy. AGC and diallylaminophosphonium salts copolymerize with $\mathrm{SO}_{2}$, both double bonds participating with formation of cis-, trans-stereoisomeric pyrrolidinium structures in a cyclolinear polymer chain 
(Table 1S in Supplementary data).

The polysulfones obtained are light powders. They are soluble due to intramolecular cyclization of AGC and diallylaminophosphonium salts during formation of polymer chains and the absence of intermolecular crosslinks. All polysulfones are soluble in methanol, DMSO, dimethylformamide; polysulfones of AGC and DAAP-Cl are also soluble in water.

The molecular weights of AGC, DAAP-Cl and DAAP-BF 4 polysulfones are 9000, 10900 and 17800 respectively.

\section{Synthesis of AgNCs}

We used our novel polysulfones as stabilizing agents in the synthesis of silver nanoparticles. Synthesis of AgNCs was conducted by the reduction of silver ions from $\mathrm{AgNO}_{3}$ with $\mathrm{NaBH}_{4}$ in aqueous (or alcoholic) solution of polysulfones. The nanocomposites obtained are dark brown powders. The content of silver in the composites was found to be in the range from 4 to 25 wt $\%$. The ratio of silver nitrate, reducing agent and copolymer significantly affects the silver concentration in nanocomposites.

The representative IR spectra of poly $\left(\mathrm{AGC}-\mathrm{SO}_{2}\right)$, poly $\left(\mathrm{DAAP}-\mathrm{Cl}-\mathrm{SO}_{2}\right)$ and poly $\left(\mathrm{DAAP}-\mathrm{BF}_{4}-\mathrm{SO}_{2}\right)$ and their AgNCs are presented in Fig. 1 . The formation of nanocomposites is accompanied by a slight change in the chemical structure of the polymer matrix. In IR spectrum of nanocomposite based on poly $\left(\mathrm{AGC}-\mathrm{SO}_{2}\right)$ increase of the band at $1299 \mathrm{~cm}^{-1}$ that belongs to the $\mathrm{SO}_{2}$ vibrations and the weak shift of this band to $1304 \mathrm{~cm}^{-1}$ can be noticed (compare IR spectra 1 and 2 in Fig. 1(A)). In IR spectrum of nanocomposite based on poly(DAAP-Cl-SO 2 ) the increase of the shoulder band at $1301 \mathrm{~cm}^{-1}$ corresponding to $\mathrm{SO}_{2}$ vibrations and the weak shift of this band to $1309 \mathrm{~cm}^{-1} \mathrm{can}$ be noticed (compare IR spectra 1 and 2 in Fig. $1(\mathrm{~B})$ ). In IR spectrum of nanocomposite based on poly(DAAP-BF $-\mathrm{SO}_{2}$ ) the poorly marked shift of the band at $1300 \mathrm{~cm}^{-1}$ to $1302 \mathrm{~cm}^{-1}$ corresponding to $\mathrm{SO}_{2}$ vibrations can be noticed (compare IR spectra 1 and 2 in Fig. 1 (C)). But no other changes are observed. This means the involvement of $\mathrm{O}$ and $\mathrm{S}$ atoms of polysulfones into interaction with silver nanoparticles.

UV-Vis absorption spectra have been proved to be quite sensitive to the formation of silver colloids since silver has the highest efficiency of plasmon resonance [39]. In general, the surface plasmon resonance peak is located between 400 and $450 \mathrm{~nm}$ for silver particles that are smaller than $100 \mathrm{~nm}$ [40]. The location and shape of the absorption peak are strongly dependent on the particle size, surrounding matrix material and dielectric medium. The peak width depends on the particle size distribution and, in addition, its height corresponds to the concentration of the silver nanoparticles.

In the UV spectra of aqueous or alcoholic solutions of the nanocomposites obtained, there are the characteristic plasmon absorption bands with a maximum in the range of 393-396 nm (Fig. 2). The position of the absorption spectra indicated a narrow size distribution without the aggregation. These peaks are shifted toward red on decreasing the polysulfone concentration that is clearly demonstrated for nanocomposite based on poly(DAAP-Cl-SO ${ }_{2}$ ) in Fig. $1 \mathrm{~S}$ in Supplementary data.

The general trend is that an increase in average size of the primary particles results in a shift of the absorption peak towards higher wavelengths [41]. The aggregation of silver nanoparticles leads to a decrease in the intensity of the peak at about $400 \mathrm{~nm}$ and also results in a long tail at the long-wavelength side of the peak [42]. In our experiments for nanocomposites based on poly $\left(\mathrm{AGC}^{-} \mathrm{SO} \mathrm{O}_{2}\right)$ and poly $\left(\mathrm{DAAP}-\mathrm{Cl}-\mathrm{SO} \mathrm{O}_{2}\right)$ only one absorption peak around $395 \mathrm{~nm}$ was observed, which is mainly attributable to primary dipolar excitation. The low intensity of the peak

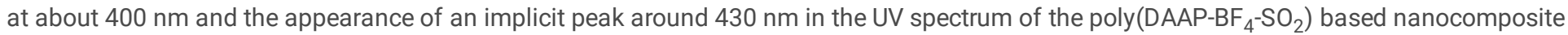
solution has been well correlated with the presence of a small fraction of microaggregates consisting of several particles [43]. However, this effect is minor because our spectra in Fig. 2 are different from the absorption features attributed to multiple polarization [44] and dipole-dipole interaction $[45,46]$ in large aggregates. This is further confirmed by microscopy results.

SEM results prove the obtaining of AgNCs with regular narrow-dispersed distribution of silver nanoparticles in polymer matrices. Silver nanoparticles of spherical and nearly spherical shape are formed. To obtain size distributions of silver nanoparticles, approximately 200 particles were counted and then combined into histograms. SEM micrographs of silver nanoparticles synthesized using polysulfones and the corresponding histograms of the size distribution are shown in Fig. 3. In our experiments the average sizes of silver nanoparticles were 12,16

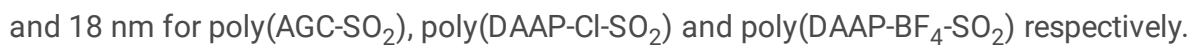

The XRD spectra of AgNCs on the basis of poly $\left(\mathrm{AGC}-\mathrm{SO}_{2}\right)$, poly $\left(\mathrm{DAAP}_{-} \mathrm{BF}_{4}-\mathrm{SO}_{2}\right)$ and poly(DAAP-Cl-SO $\left.{ }_{2}\right)$ are shown in Fig. 4. Four main diffraction peaks were observed at around $38^{\circ}, 44^{\circ}, 65^{\circ}$ and $78^{\circ}$ under the diffraction angle $2 \theta=10-80^{\circ}$ and can be indexed to the $(111)$, $(20$ 0), (2 20 ) and (3 11 1) planes which corresponded to the four faces of silver cube crystal according to the standard specimen [JCPDS file № 040783], indicating the silver exited the cube crystal. The crystal diffraction peaks were dilated obviously because of the effect of the nanometer particles. The average crystallite sizes of silver nanoparticles were estimated using Scherrer's equation [47] from the peak width of (1 11 ) 
reflection plane and were found to be $12.5,16.7$ and $18.4 \mathrm{~nm}$ for poly $\left(\mathrm{AGC}-\mathrm{SO}_{2}\right)$, poly $\left(\mathrm{DAAP}-\mathrm{Cl}_{-} \mathrm{SO}_{2}\right)$ and poly $\left(\mathrm{DAAP} \mathrm{BF}_{4}-\mathrm{SO}_{2}\right)$ respectively. It should be noticed that XRD data concerning the size of silver nanoparticles are consistent with SEM results.

These experimental results are in a reasonable good agreement with DLS measurements (Fig. 2S in Supplementary data), where the sizes of silver nanoparticles were 9.9, 17.6 and $19.1 \mathrm{~nm}$ for poly $\left(\mathrm{AGC}-\mathrm{SO}_{2}\right)$, poly $\left(\mathrm{DAAP}-\mathrm{Cl}-\mathrm{SO}_{2}\right)$ and poly $\left(\mathrm{DAAP} \mathrm{BF}_{4}-\mathrm{SO}_{2}\right)$ respectively.

Importantly, even after three months, the aqueous dispersions of AgNCs displayed UV spectral characteristics of spherical silver nanoparticles, confirming the colloidal stability and uniformity of the silver hydrosol, as distinctly demonstrated for nanocomposite based on poly(DAAP-Cl$\mathrm{SO}_{2}$ ) in Fig. $3 \mathrm{~S}$ in Supplementary data.

The antimicrobial activity of silver nanoparticles is size dependent [10]. Silver nanoparticles should be small enough to pass through the cell membrane. Therefore, the influence of molecular weight of copolymer, the polysulfone concentration and $\mathrm{Ag}^{+}$concentration on the size of $\mathrm{Ag}$ nanoparticles was investigated (Table 2S, 3S and 4S in Supplementary data). Tables illustrated that when molecular weight of the polysulfone, the polysulfone concentration and the $\mathrm{Ag}^{+}$concentration increased, the average size of particles decreased for all systems. Polysulfones affect the molecular motion of reduced silver and subsequently limit the aggregation of nanoparticles. Therefore, we can prepare nanocomposites containing silver nanoparticles with convenient and controlled size.

\section{Antimicrobial activity of nanocomposites}

Our previous studies of antimicrobial activity showed that polysulfones exhibit pronounced bactericidal effect [48, 49] (Table 1). The polysulfone concentration of 7.8-31.2 $\mu \mathrm{g} / \mathrm{mL}$ ensured $100 \%$ reduction of Staphylococcus aureus and Micrococcus luteus. The poly(DAAP-Cl$\mathrm{SO}_{2}$ ) and poly $\left(\mathrm{DAAP}_{-} \mathrm{BF}_{4}-\mathrm{SO}_{2}\right)$ at concentration of $62.5 \mu \mathrm{g} / \mathrm{mL}$ and poly $\left(\mathrm{AGC}-\mathrm{SO}_{2}\right)$ at concentration of $500 \mu \mathrm{g} / \mathrm{mL}$ inhibited $100 \%$ Escherichia coli.

Table 1

Antimicrobial activity of polysulfones $[42,43]$ and their silver nanocomposites

\begin{tabular}{|c|c|c|c|c|c|c|c|}
\hline \multirow[t]{2}{*}{$\mathbf{N}$} & \multirow[t]{2}{*}{ Test cultures } & \multicolumn{6}{|c|}{ Minimal bacteriostatic concentration (MBsC), $\mu \mathrm{g} / \mathrm{ml}$} \\
\hline & & $\begin{array}{l}\text { poly(AGC- } \\
\left.\mathrm{SO}_{2}\right)\end{array}$ & $\begin{array}{l}\text { nano } \\
\text { poly(AGC- } \\
\left.\mathrm{SO}_{2}\right)\end{array}$ & $\begin{array}{l}\text { poly(DAAP- } \\
\left.\mathrm{BF}_{4}-\mathrm{SO}_{2}\right)\end{array}$ & $\begin{array}{l}\text { nano } \\
\text { poly(DAAP- } \\
\left.\mathrm{BF}_{4}-\mathrm{SO}_{2}\right)\end{array}$ & $\begin{array}{l}\text { poly(DAAP- } \\
\left.\mathrm{Cl}^{-\mathrm{SO}_{2}}\right)\end{array}$ & $\begin{array}{l}\text { nano poly(DAAP- } \\
\mathrm{Cl}^{-\mathrm{SO}_{2}} \text { ) }\end{array}$ \\
\hline 1 & Escherichia coli, ATCC 25922 & 500 & 62.5 & 62.5 & 31.2 & 62.5 & 31.2 \\
\hline 2 & $\begin{array}{l}\text { Staphylococcus aureus, ATCC } \\
25923\end{array}$ & 7.8 & 3.9 & 15.6 & 7.8 & 7.8 & 7.8 \\
\hline 3 & $\begin{array}{l}\text { Micrococcus luteus, NCIMB } \\
196\end{array}$ & 31.2 & 15.6 & 15.6 & 7.8 & 7.8 & 3.9 \\
\hline 4 & $\begin{array}{l}\text { Staphylococcus epidermidis } \\
33\end{array}$ & 31.2 & 7.8 & 15.6 & 3.9 & 3.9 & 3.9 \\
\hline 5 & $\begin{array}{l}\text { Staphylococcus epidermidis, } \\
\text { ATCC } 29887\end{array}$ & 500 & 125 & 62.5 & 31.2 & 62.5 & 62.5 \\
\hline 6 & Salmonella spp. & 1000 & 62.5 & 125.0 & 125.0 & 125.0 & 62.5 \\
\hline 7 & Bacillus subtilis, ATCC 6633 & 500 & 125 & 31.2 & 15.6 & 62.5 & 31.2 \\
\hline 8 & $\begin{array}{l}\text { Pseudomonas aeruginosa, } \\
\text { ATCC } 27853\end{array}$ & 500 & 62.5 & 31.2 & 15.6 & 31.2 & 15.6 \\
\hline
\end{tabular}

The antimicrobial activity of AgNCs with respect to Gram positive and Gram negative bacteria was also determined (Table 1). We can see that nanocomposites have a high activity against both Gram positive and Gram negative microflora. It is seen that biocide effect of new AgNCs is generally higher as compared to initial polysulfones. Minimum bacteriostatic concentrations of nanocomposites based on polyphosphonium salts and poly $\left(\mathrm{AGC}_{\mathrm{SO}}\right)$ against $S$. epidermidis 33 are equal to 3.9 and $7.8 \mu \mathrm{g} / \mathrm{mL}$ respectively. All nanocomposites at concentration of $3.9-$ $15.6 \mu \mathrm{g} / \mathrm{mL}$ inhibited $100 \%$ Micrococcus luteus and Staphylococcus aureus. The poly $\left(\mathrm{DAAP}^{-C l-S O_{2}}\right)$ and poly $\left(\mathrm{DAAP}_{-} \mathrm{BF}_{4}-\mathrm{SO}_{2}\right)$ nanocomposite concentration of $31.2 \mu \mathrm{g} / \mathrm{mL}$ ensured $100 \%$ reduction of Escherichia coli.

\section{Effect of polysulfones and their nanocomposites on biofilm formation}

More than $99 \%$ of bacteria exist in natural ecosystems not in the form of freely floating cells, but in the form of biofilms attached to the substrate. The microflora of the biofilm is more resistant to the effects of adverse physical, chemical and biological factors compared to 
plankton cells. Microorganisms form biofilms on any biotic and abiotic surfaces, which creates great problems in medical practice and in various fields of economic activity. Therefore, the study of the effect of antimicrobial compounds on bacterial biofilms is relevant.

To study the effect of antimicrobial compounds on biofilms, water-soluble poly $\left(\mathrm{AGC}^{-\mathrm{SO}_{2}}\right)$ and poly $\left(\mathrm{DAAP}-\mathrm{Cl}-\mathrm{SO}_{2}\right)$ and their $\mathrm{AgNCs}$ were selected.

Figure 5 illustrates the effects of poly $\left(\mathrm{AGC}-\mathrm{SO}_{2}\right)$ and poly $\left(\mathrm{DAAP}-\mathrm{Cl}-\mathrm{SO}_{2}\right)$ and their silver nanocomposites on the biofilm formation evaluated by the absorbance of crystal violet at $\mathrm{A}_{570}$ for bacteria S. epidermidis 33 and Escherichia coli.

The noticeable decrease of the bacterial mass in the S. epidermidis 33 biofilm detected as $\mathrm{A}_{570}$ absorbance was observed when nanocomposite concentration was $>3.9 \mu \mathrm{g} / \mathrm{mL}$ (Fig. $5 \mathrm{~A}$ ). The use of the nanocomposite based on poly $\left(\mathrm{AGC}^{\mathrm{S} \mathrm{S}_{2}}\right.$ ) in the concentration of $31.2 \mu \mathrm{g} / \mathrm{mL} \mathrm{makes} \mathrm{it}$ possible to completely prevent the formation of $S$. epidermidis 33 biofilm.

As is seen from Fig. 5B, the use of poly (DAAP-Cl-SO $\mathrm{S}_{2}$ ) and its silver nanocomposite does not prevent the Escherichia coli biofilm formation and furthermore stimulates this process. The use of silver nanocomposite based on poly(AGC-SO ${ }_{2}$ ) at the concentration above $250 \mu \mathrm{g} / \mathrm{mL}$ noticeably prevents the formation of Escherichia coli biofilms.

\section{Effect of polysulfones and their nanocomposites on the developed biofilms}

Biofilm formation was carried out on glass slides, and cells were grown in the stationary conditions without shaking. After the biofilm formation during $24 \mathrm{~h}$, the cultured liquid containing planktonic cells was removed and a fresh medium containing tested compounds was added.

Figure 6 illustrates the effects of poly $\left(\mathrm{AGC}-\mathrm{SO}_{2}\right)$ and poly $\left(\mathrm{DAAP}-\mathrm{Cl}-\mathrm{SO}_{2}\right)$ and their $\mathrm{AgNCs}$ on the developed biofilms for bacteria S. epidermidis 33 and Escherichia coli. Analysis of biofilms with crystal violet staining showed that it is possible to destruct by $30 \%$ the developed $S$. epidermidis 33 biofilms (within $24 \mathrm{~h}$ ) using the poly $\left(\mathrm{DAAP}-\mathrm{Cl}-\mathrm{SO}_{2}\right.$ ) and its silver nanocomposite (Fig. 6A). At concentration of $125 \mu \mathrm{g} / \mathrm{mL}$ for poly $\left(\right.$ AGC-SO ${ }_{2}$ ) and of $62.5 \mu \mathrm{g} / \mathrm{mL}$ for its silver nanocomposite the biomass of the $S$. epidermidis 33 biofilms was reduced by half. The use of the AgNCs based on the poly $\left(\mathrm{AGC}^{-\mathrm{SO}_{2}}\right)$ at the concentration above $500 \mu \mathrm{g} / \mathrm{mL}$ makes it possible to almost completely destruct the developed S. epidermidis 33 biofilm.

Figure 6B shows that poly(DAAP-Cl-SO ${ }_{2}$ ) and its nanocomposite at a concentration of more than $600-700 \mu \mathrm{g} / \mathrm{mL}$ destroy Escherichia coli biofilms and vice versa, at lower concentrations, they stimulate further biofilm formation. A similar effect is observed for poly $\left(\mathrm{AGC}-\mathrm{SO} \mathrm{O}_{2}\right)$. This polysulfone at a concentration of more than $1000 \mu \mathrm{g} / \mathrm{mL}$ destroys the Escherichia coli biofilms, at lower concentrations there is an accelerated process of biofilm formation. At concentration of $1000 \mu \mathrm{g} / \mathrm{mL}$ for poly $\left.\left(\mathrm{AGC}_{\mathrm{SO}}\right)_{2}\right)$ silver nanocomposite the biomass of the Escherichia coli biofilm was reduced by half.

\section{Toxicity of AgNCs}

Our results indicate a high antimicrobial effect of silver nanocomposites on pathogenic bacteria and, as a result, a beneficial impact on human health. However, the silver nanoparticles may cause adverse effects. Therefore, the investigation of biocides is impossible without their toxicity testing.

Polysulfones and their silver nanocomposites were found to be nontoxic (the $\mathrm{LD}_{50}$ values were more $1000 \mathrm{mg} / \mathrm{kg}$ ) and therefore could be used for medical purposes.

With increased exposure of silver nanoparticles to human beings, their biocompatibility requires further research in terms of cytotoxicity.

Cytotoxicity of AgNCs with respect to cell lines, namely the Bronchial carcinoma (A549), Rhabdomyosarcoma (RD), Melanoma (MS) and Human Embryonic Kidney (HEK293) was evaluated in vitro by MTT-test (Table 2). After $72 \mathrm{~h}$ cultivation with the AgNCs at the $100-1.56 \mu \mathrm{M}$ concentration, cell viability was evaluated. The cell viability in control wells was not less than $95 \%$. In the wells containing $5.35 \mu \mathrm{M}$ of $\mathrm{AgNC}$

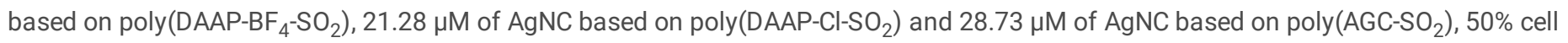
viability of the $M S$ line cells is observed. $50 \%$ of the $R D$ line cells was not survived in the wells containing $12.17 \mu \mathrm{M}$ and $21.28 \mu \mathrm{M}$ of AgNCs

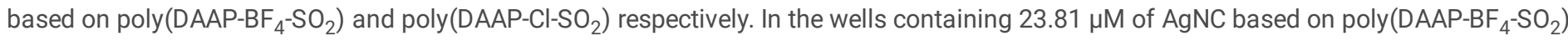
and $40.37 \mu \mathrm{M}$ of AgNC based on poly(DAAP-Cl-SO 2$), 50 \%$ cell viability of the $A 549$ line cells is observed. The AgNC based on poly $\left(\mathrm{AGC}^{-} \mathrm{SO}_{2}\right)$ had exhibited lower activity with respect to $A 549$ and $R D$ line cells. An important property of nanocomposites is the absence of a cytotoxic effect with respect to pseudonormal HEK293 cell line. 
Table 2

Cytotoxic activity of polysulfones and AgNCs

\begin{tabular}{|c|c|c|c|c|c|c|c|c|}
\hline \multirow[t]{2}{*}{ Culture } & \multicolumn{8}{|l|}{$\mathrm{IC}_{50}, \mu \mathrm{M}$} \\
\hline & Camptothecin & Doxorubicin & $\begin{array}{l}\text { poly(AGC- } \\
\left.\mathrm{SO}_{2}\right)\end{array}$ & $\begin{array}{l}\text { nano } \\
\text { poly(AGC- } \\
\left.\mathrm{SO}_{2}\right)\end{array}$ & $\begin{array}{l}\text { poly(DAAP- } \\
\left.\mathrm{BF}_{4}-\mathrm{SO}_{2}\right)\end{array}$ & $\begin{array}{l}\text { nano } \\
\text { poly(DAAP- } \\
\left.\mathrm{BF}_{4}-\mathrm{SO}_{2}\right)\end{array}$ & $\begin{array}{l}\text { poly(DAAP- } \\
\mathrm{Cl}^{-\mathrm{SO}_{2}} \text { ) }\end{array}$ & $\begin{array}{l}\text { nano } \\
\text { poly(DAAP- } \\
\mathrm{Cl}^{-\mathrm{SO}_{2}} \text { ) }\end{array}$ \\
\hline $\begin{array}{l}\text { Rhabdomyosarcoma } \\
\text { RD }\end{array}$ & $1.72 \pm 0.37$ & $1.28 \pm 0.03$ & $>200$ & $>200$ & $\begin{array}{l}148.3 \pm \\
4.70\end{array}$ & $\begin{array}{l}12.17 \pm \\
1.31\end{array}$ & $\begin{array}{l}97.16 \pm \\
2,26\end{array}$ & $\begin{array}{l}17.89 \pm \\
1.65\end{array}$ \\
\hline $\begin{array}{l}\text { Bronchial carcinoma } \\
\text { A549 }\end{array}$ & $1.31 \pm 0.03$ & $2.04 \pm 0.22$ & $>200$ & $>200$ & $>200$ & $\begin{array}{l}23.81 \pm \\
0.47\end{array}$ & $>200$ & $\begin{array}{l}40.37 \pm \\
0.93\end{array}$ \\
\hline Melanoma MS & $0.77 \pm 0.34$ & $1.29 \pm 0.16$ & $>200$ & $\begin{array}{l}28.73 \pm \\
1.01\end{array}$ & $\begin{array}{l}131.5 \pm \\
0.85\end{array}$ & $5.35 \pm 1.25$ & $>200$ & $\begin{array}{l}21.28 \pm \\
1.01\end{array}$ \\
\hline $\begin{array}{l}\text { Human embryonic } \\
\text { kidney Hek293 }\end{array}$ & $1.61 \pm 1.08$ & $0.44 \pm 0.04$ & $>200$ & $\begin{array}{l}115.2 \pm \\
6.68\end{array}$ & $>200$ & $\begin{array}{l}77.87 \pm \\
10.23\end{array}$ & $>200$ & $\begin{array}{l}84.85 \pm \\
4.75\end{array}$ \\
\hline
\end{tabular}

\section{Discussion}

Many of the interesting properties of silver nanoparticles, which gave rise to their vast applications in biology and medicine, are highly dependent on the size and shape of the nanoparticles as well as their compositions. As stated in [50], differences in the chemical and physical properties of nanosilver can lead to the observed variations in its antimicrobial and antibiofilm efficacy.

Because of the relatively low stability of colloidal solutions, numerous reports are devoted to investigations of stabilized silver nanoparticles [15-25]. A suitable stabilizer should be used to limit the growth of the silver particles and their aggregation. Our new polysulfones were used as the stabilizing matrices for silver nanoparticles. We believe that poly $\left(\mathrm{AGC}-\mathrm{SO}_{2}\right)$, poly $\left(\mathrm{DAAP}-\mathrm{Cl}-\mathrm{SO}_{2}\right)$ and poly $\left(\mathrm{DAAP}-\mathrm{BF}_{4}-\mathrm{SO}_{2}\right)$ are the good stabilizers for silver particles. In IR spectra of nanocomposites the change of the band at around $1300 \mathrm{~cm}^{-1}$ that belongs to the $\mathrm{SO}_{2}$ vibrations can be noticed. Thus, we can talk about the involvement of $\mathrm{O}$ and $\mathrm{S}$ atoms of polysulfones into interaction with silver nanoparticles. Our results prove polysulfone interacting with silver particles through the oxygen atom in $\mathrm{S}=0$ group. We believe that the surface of silver nanoparticles is passivated through the coordination of the $\mathrm{SO}_{2}$ groups. This further confirms the significant role of chemisorption in the interaction of $\mathrm{O}$ and $\mathrm{S}$ atoms of polysulfones with silver nanoparticles. Ultimately, these polysulfones provide a very good covering for silver particles, preventing particle growth and the formation of large aggregates. Indeed, the reduction of silver nitrate in the presence of polysulfones leads to small silver particles $(12-18 \mathrm{~nm})$ and narrow particle size distribution.

In the last decade, there has been a surplus of investigations applying the concept of silver nanoparticles as antibacterial, antifungal and antiviral agents [51]. Silver nanoparticles have been demonstrated to be effective against burn infections, severe chronic osteomyelitis, urinary tract infections and central venous catheter infections. Silver nanoparticles are perspective as antimicrobial agents for different medical devices [52] and as a bioactive material for food packaging [53].

Action mechanism of silver nanoparticles on microorganisms is rather complicated and has not been ascertained completely. It has been suggested [54] that the nanoparticles get attached to the cell membrane and also penetrate inside the bacteria. The bacterial membrane contains sulfur-containing proteins and the silver nanoparticles interact with these proteins in the cell as well as with phosphorous-containing compounds like DNA. The nanoparticles preferably attack the respiratory chain, cell division finally leading to cell death. The nanoparticles release silver ions in the bacterial cells, which enhance their bactericidal activity [10, 55-57].

We can see from Table 1 that biocide effect of our nanocomposites is higher as compared to initial polysulfones. This confirms the significant role of silver nanoparticles in the biocide effect of nanocomposites. Moreover, the effectiveness of the nanocomposites against $S$. epidermidis 33 and $S$. aureus is higher as compared with that against Escherichia coli. It could be explained the thick peptidoglycan layer within the cell wall of Gram-positive bacteria which contains teichoic and lipoteichoic acids which act as chelating agents and could take part in the neutralization of silver ions.

It was shown that administration of silver compounds in different materials prevented bacterial biofilm formation [58]. The antibiofilm activity of silver nanoparticles is briefly described in a number of studies [59-68]. It has been shown that inactivation of bacteria in biofilms occurs at silver nanoparticle concentrations 5-20 times higher than those inhibiting completely the planktonic cells and biofilm formation $[67,68]$.

As is seen from Fig. $5 \mathrm{~A}$, the copolymers prevent $\mathrm{S}$. epidermidis 33 biofilm formation while poly $\left(\mathrm{AGC}^{-} \mathrm{SO}_{2}\right)$ is more active. We expected that the incorporation of silver nanoparticles into biocide polymer matrices will enhance their antimicrobial and antibiofilm activity. The polymers 
having a quaternary ammonium and phosphonium groups can destroy the membrane of bacterial cells and cause leakage of intracellular contents $[69,70]$, therefore, inhibiting the growth of bacteria effectively. Our investigations showed that the combination of two biocide centers in nanocomposites results in the synergistic enhancement of antibacterial properties of new nanocomposites. Indeed, the introduction of silver nanoparticles into polysulfones reduced the nanocomposite concentration, at which the formation of $\mathrm{S}$. epidermidis 33 biofilm can be completely prevented.

At the same time the treatment of the developed $\mathrm{S}$. epidermidis 33 biofilms with poly $\left(\mathrm{AGC}-\mathrm{SO}_{2}\right)$ or its silver nanocomposite (at the concentrations of 125 and $62.5 \mu \mathrm{g} / \mathrm{mL}$ respectively) resulted in the destruction half of the biomass of biofilm (Fig. $6 \mathrm{~A}$ ). This indicates the contribution of the biocide guanidine group of copolymer in the destruction of the biofilms. Figure $6 \mathrm{~A}$ shows that $30 \%$ of the developed $S$. epidermidis 33 biofilms can be destroyed using poly (DAAP-Cl-SO $\mathrm{S}_{2}$ ) and its silver nanocomposite, and the anti-biofilm effect of poly (DAAP-Cl$\mathrm{SO}_{2}$ ) and its silver nanocomposite is the same. That means the significant role of biocide guanidinium and phosphonium polymers in the destruction of the developed S. epidermidis 33 biofilms.

A different picture is observed with Escherichia coli biofilms. From Fig. 5B it is seen that silver nanocomposite based on poly(AGC-SO $\left.{ }_{2}\right)$ noticeably prevents the formation of Escherichia coli biofilms but the nanocomposite concentration must to be more as compared with $S$. epidermidis 33 biofilm. Given the lack of anti-film activity of the poly (AGC-SO $\left.{ }_{2}\right)$ itself, we can speak about the significant role of silver nanoparticles in the preventing Escherichia coli biofilm formation.

Surprisingly, poly(DAAP-Cl-SO ${ }_{2}$ ) and its silver nanocomposite stimulate Escherichia coli biofilm formation (Fig. 5B). In addition, a study of the effect of the compounds on the developed Escherichia coli biofilms shows (Fig. 6B) that the above polysulfone and its nanocomposite destroy Escherichia coli biofilms at high concentrations, and at low concentrations they stimulate further biofilm formation. Earlier, a number of authors noticed this phenomenon. Hoffman et al. revealed the stimulating effect of sub-inhibitory concentrations of antibiotics on Escherichia coli biofilm formation [71]. Wu et al. found that exposure to sub-inhibitory concentrations of antibiotic cause the bacteria to increase glycogen synthesis while turning down a broad range of other metabolic processes [72]. Thus, this fact can be explained by the ability of phosphonium salt and its nanocomposite at low concentrations to accelerate the formation of Escherichia coli biofilms in the response to stressful environmental factors.

In addition, it can be noted that Escherichia coli biofilms are more resistant to the action of our antimicrobial substances compared to $S$. epidermidis 33 biofilms. Gram-negative bacteria are characterized by their cell envelopes, which are composed of a thin peptidoglycan cell wall, sandwiched between an inner cytoplasmic cell membrane and a bacterial outer membrane. This outer membrane protects the Gram-negatives from many antibiotics that could otherwise damage the peptidoglycan layer or the inner cell $[73,74]$.

Silver nanoparticles are widely used as antimicrobial agents. Due to the increased use of nanosilver and related materials, it was necessary to study the possible adverse effects and toxicity $[39,51]$.

Silver nanocomposites were evaluated for their potential cytotoxicity. Metal-polymer nanocomposites are considered as promising new generation drugs for the treatment of cancer tumors [75]. The use of metal-polymer structures for anticancer therapy opens up unique opportunities for combating those types of tumors that cannot be treated with known drugs. Such drugs should have a selective cytotoxic effect on tumor cells and not have a stimulating effect on metastatic processes. The introduction of nanomaterials into the production of medical preparations requires a detailed study of the particle effect not only on tumor cells, but also on healthy cells of the body. Therefore, the cytotoxicity of the synthesized copolymers and nanocomposites was determined both on cultures of human tumor cells and on cultures of pseudonormal human cells.

As is apparent from Table 2, new nanocomposites based on poly(DAAP-BF $\left.{ }_{4}-\mathrm{SO}_{2}\right)$ and poly $\left(\mathrm{DAAP}-\mathrm{Cl}-\mathrm{SO}_{2}\right)$ exhibit significant activity against $R D$ and $M S$ tumor line cells. The level of cytotoxic activity of the obtained nanocomposites is not inferior to the alkaloid with high antitumor activity, camptothecin, and the antibiotic with antitumor activity, doxorubicin. Given the lack of cytotoxic activity with respect to pseudonormal HEK293 cell line and significant activity against both RD and MS line cells, one can speak of a high selectivity of silver nanocomposites.

\section{Conclusions}

Thus, new silver nanocomposites based on poly $\left(\mathrm{AGC}-\mathrm{SO}_{2}\right)$, poly $\left(\mathrm{DAAP}-\mathrm{Cl}_{-} \mathrm{SO}_{2}\right)$ and poly $\left(\mathrm{DAAP}-\mathrm{BF}_{4}-\mathrm{SO}_{2}\right)$ have been developed. The AgNCs are well characterized by using different techniques to confirm the formation of silver nanoparticles with average size of $12-18 \mathrm{~nm}$.

Antibacterial activity of new silver nanocomposites with respect to $S$. epidermidis 33 and Escherichia coli (planktonic cells and biofilms) is reported in this study. The noticeable decrease of the bacterial mass in S. epidermidis 33 biofilms was observed when nanocomposite concentration was $>3.9 \mu \mathrm{g} / \mathrm{mL}$. It is possible to completely prevent the $S$. epidermidis 33 biofilm formation at concentration above $31.2 \mu \mathrm{g} / \mathrm{mL}$ for nanocomposite based on poly $\left(\mathrm{AGC}-\mathrm{SO}_{2}\right)$. The mentioned nanocomposite at the concentration above $250 \mu \mathrm{g} / \mathrm{mL}$ noticeably prevents the 
formation of Escherichia coli biofilms while the use of poly (DAAP-Cl-SO ${ }_{2}$ ) nanocomposite stimulates this process due to the response to stressful environmental factors. Nanocomposite based on poly $\left(A G C-\mathrm{SO}_{2}\right)$ at the concentration above $500 \mu \mathrm{g} / \mathrm{mL}$ destroys the developed $S$. epidermidis 33 biofilms while the use of nanocomposite based on poly (DAAP-Cl-SO $\mathrm{S}_{2}$ ) allows to destruct the developed $\mathrm{S}$. epidermidis 33

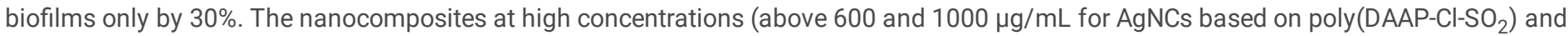
poly $\left(\mathrm{AGC}_{\mathrm{SO}}\right.$ ) respectively) destroy the developed Escherichia coli biofilms, but at lower concentrations an accelerated process of biofilm formation is observed. The results for AgNCs show that the nanocomposite concentration destructing biofilms is higher than preventing biofilm formation.

AgNCs are nontoxic, and nanocomposites based on diallylaminophosphonium polysulfones exhibit significant selective cytotoxic activity against $R D$ and $M S$ cells.

The utilization of polysulfones in the synthesis of silver nanoparticles presented a number of possibilities for further development, in particular, for the preparation of nontoxic functional materials for biomedical applications.

\section{Declarations}

\section{Funding}

Financial support by the Russian Foundation for Basic Research and Government of the Perm Region (grant № 19-43-590019-r_a) is gratefully acknowledged.

\section{Conflicts of interest/Competing interests}

No potential competing interest was reported by the authors.

\section{References}

1. R.R.G. Killivalavan, A.Ch. Prabakar, K.Ch.B. Naidu, B. Sathyaseelan, G. Rameshkumar, D. Sivakumar, K. Senthilnathan, I. Baskaran, E. Manikandan, Biointerface. Res. Appl. Chem. 10(2), 5306-5311 (2020) DOI: 10.33263/BRIAC102.306311

2. A. Yaqoob, H. Ahmad, T. Parveen, A. Ahmad, M. Oves, I. M. I. Ismail, H.A. Qari, Kh. Umar, M.N.M. Ibrahim, Front. Chem. 8, 1-23 (2020) DOI: 10.3389/fchem.2020.00341

3. B. Yaqoob, R. Adnan, R. M. R. Khan, M. Rashid, Front. Chem. 8, 1-15 (2020) DOI: 10.3389/fchem.2020.00376

4. Klębowski, J. Depciuch, M. Parlińska-Wojtan, J. Baran, Int. J. Mol. Sci. 19(12), 4031 (2018) DOI:10.3390/ijms19124031

5. Rai, A.P. Ingle, S. Birla, A. Yadav, C.A. Dos Santos, Crit. Rev. Microbiol. 1-24 (2015) DOI: 10.3109/1040841X.2015.1018131

6. A. Krutyakov, A.A. Kudrinskiy, A.Yu. Olenin, G.V. Lisichkin, Russ. Chem. Rev. 77, 233-257 (2008) D0I:10.1070/RC2008v077n03ABEH003751

7. García-Barrasa, J.M. López-de-Luzuriaga, M. Monge, Cent. Eur. J. Chem. 9, 7-19 (2011) DOI:10.2478/s11532-010-0124-x

8. Henglein, Chem. Rev. 89, 1861-1873 (1989) DOI: 10.1021/cr00098a010

9. Silver, FEMS Microbiol. Rev. 27, 341-353 (2003) DOI:10.1016/S0168-6445(03)00047-0

10. R. Morones, J.L. Elechiguerra, A. Camacho, K. Holt, J.B. Kouri, J. Tapia Ramirez, M.J. Yacaman, Nanotechnology. 200516, 2346-2353 (2005) DOI:10.1088/0957-4484/16/10/059

11. E. Afinogenov, E.F. Panarin, Antimicrobial polymers (Hippocrates, Saint-Petersburg, 1993)

12. A. Dos Santos, M.M. Seckler, A.P. Ingle, I. Gupta, S. Galdiero, M. Galdiero, A. Gade, M. Rai, J. Pharm. Sci. 103, 1931-1944 (2014) DOI: 10.1002/jps.24001

13. V. Vegera, A.D. Zimon, Russ. J. Appl. Chem. 79, 1403-1406 (2006) DOI: 10.1134/S1070427206090023

14. R. Saifullina, G.A. Chiganova, S.V. Karpov, V.V. Slabko, Russ. J. Appl. Chem. 79, 1639-1642 (2006) D0I: 10.1134/S1070427206100168

15. He, J. Yao, P. Jiang, D. Shi, H. Zhang, S. Xie, S. Pang, H. Gao, Langmuir. 7, 1571 -1575 (2001) D0I: 10.1021/la001239w

16. Li, J. Zhang, W. Xu, H. Jia, X. Wang, B. Yang, B. Zhao, B. Li, Y. Ozaki, Langmuir. 19, 4285-4290 (2003) DOI: 10.1021/la0341815

17. Sondi, D.V. Goia, E. Matijevic', J. Colloid. Interface Sci. 260, 75-81 (2003) DOI: 10.1016/s0021-9797(02)00205-9

18. P. Cason, K. Khambaswadkar, C.B. Roberts, Ind. Eng. Chem. Res. 39, 4749 - 4755 (2000) DOI: 10.1021/ie000147z

19. Chen, D.L. Carroll, Nano Letters. 2, 1003 - 1007 (2002) DOI: 10.1021/nl025674h

20. P. Velikov, G.E. Zegeres, A. van Blaaderen, Langmuir. 19, 1384-1389 (2003) DOI: 10.1021/la026610p

21. Tan, X. Dai, Y. Li, D. Zhu, J. Mater. Chem. 13, 1069-1075 (2003) DOI: 10.1039/B211386D

22. Wang, P. Wei, S. Stumpf, U.S. Schubert, S. Hoeppener, Nanotechnology. 31, 465604 (2020) DOI: 10.1088/1361-6528/abab2d 
23. K. Tiwari, M.K. Gupta, G. Pandey, R.J. Narayan, P.C. Pandey, J. Mater. Res. 35, 2405-2415 (2020) DOI: 10.1557/jmr.2020.183

24. Esumi, A. Suzuki, A. Yamahira, K. Torigoe, Langmuir. 16, 2604-2608 (2000) DOI: 10.1021/la991291w

25. M. Crooks, M. Zhao, L. Sun, V. Chechik, L.K. Yeung, Acc. Chem. Res. 34, 181-190 (2001) DOI: 10.1021/ar000110a

26. Gorbunova, L. Lemkina, D. Eroshenko, K. Gileva, Polym. Adv. Tech. 30, 336-343 (2019) DOI: 10.1002/pat.4470

27. Zhang, J. Liu, K. Cui, T. Jiang, Zh. Ma, Progress in Chemistry. 31, 681-689 (2019) DOI: 10.7536/PC180930

28. N. Gorbunova, in Encyclopedia of Biomedical Polymers and Polymeric Biomaterials, ed. by M. Mishra (CRC Press, New York, 2015) pp. 3672-3680 DOI:10.1081/E-EBPP-120049929

29. Gilbert, L.T. Moore, J. Appl. Microbiol. 99, 703-715 (2005) DOI: 10.1111/j.1365-2672.2005.02664.x

30. Zhang, J. Jiang, Y. Chen, Polymer. 40, 6189-6198 (1999) DOI: 10.1016/S0032-3861(98)00828-3

31. Qian, Y. Guan, B. He, H. Xiao, Polymer. 49, 2471-2475 (2008) DOI: 10.1016/j.polymer.2008.03.042

32. El-R. Kenawy, F.I. Abdel-Hay, A. El-Raheem, R. El-Shanshoury, M.H. El-Newehy, J. Control. Release. 50, 145-152 (1998) DOI: 1016/s01683659(97)00126-0

33. El-R.Kenawy, S.D. Worley, R. Broughton, Biomacromolecules. 8, 1359-1384 (2007) DOI: 1021/bm061150q

34. H. El-Newehy, El-R. Kenawy, S.S. Al-Deyab, Inter. J. Polym. Mater. Polym. Biomater. 63, 758-766 (2014) DOI: 10.1080/00914037.2013.879448

35. Zhang, L. Wang, Q. Chen, Ch. Chen, Yonsei Med. J. 55, 283-291 (2014) DOI:10.3349/ymj.2014.55.2.283

36. Gorbunova, A. Vorob'eva, A. Tolstikov, Yu.B. Monakov, Polym. Adv. Tech. 20, 209-215 (2009)DOl:10.1002/pat.1253

37. N. Gorbunova, A.I. Vorob'eva, Macromol. Symp. 298, 160-166 (2010) DOI: 10.1002/masy.201000044

38. B. Prozorovskiy, M.P. Prozorovskaya, V.M. Demchenko, Pharmacol and toxicol. 4, 497-502 (1978)

39. Kreibig, M. Vollmer, Optical properties of metal clusters (Springer-Verlag, New York, 1995)

40. Henglein, Chem. Mater. 10, 444-450 (1998) DOI: S0897-4756(97)00613-3

41. M. Heard, F. Greiser, C.G. Barraclough, J.V. Sanders, Colloid. Interface Sci. 93, 545-555 (1983) D0I: 10.1016/0021-9797(83)90439-3

42. H. Huang, X.P.Ni, G.L. Loy, C.H. Chew, K.L. Tan, F.C. Loh, J.F. Deng, G.Q. Xu, Langmuir. 12, 909-912 (1996) DOI: 10.1021/la950435d

43. Mulvaney, Langmuir. 12, 788-800 (1996) DOI: 10.1021/la9502711

44. Kreibig, P. Zacharias, Z. Phys. 231, 128-143 (1970) DOI: 10.1007/BF01392504

45. Kreibig, M. Quinten, D. Schoenauer, Physica A. 157, 244-261 (1989) DOI: 10.1016/0378-4371(89)90310-5

46. Quinten, U. Kreibig, Surf. Sci. 172, 557-577 (1986) DOI:10.1016/0039-6028(86)90501-7

47. Scherrer, Nachr Ges Wiss Goettingen, Math-Phys KI. 1918, 98-100 (1918) German.

48. N. Gorbunova, A.I. Vorob'eva, G.A. Aleksandrova, I.N. Kiryanova, Pharm. Chem. J. 43, 13-16 (2009)

49. N. Gorbunova, A.I. Vorob'eva, G.A. Aleksandrova, A.G. Tolstikov, Patent RU № 2365596 (2009)

50. Markowska, A.M. Grudniak, K.I. Wolska, Acta Biochim. Pol. 60, 523-530 (2013) PMID: 24432308

51. Durán, P.D. Marcato, R. de Conti, O.L. Alves, F.T.M. Costa, M. Brocchi, J. Braz. Chem. Soc. 21, 949-959 (2010) DOI: 10.1590/S010350532010000600002

52. Haddadine, S. Chalal, K. Abouzeid, N. Bouslah, A. Benaboura, M.S. El-Shall, Polym. Adv. Technol. 29, 1107-1116 (2018) DOI: $10.1002 /$ pat.4222

53. Jiraroj, S.Tungasmita,D.N.Tungasmita, J. Appl. Polym. Sci.134, 45450 (2017) DOI: 10.1002/app.45450

54. Rai, A. Yaclav, A. Gade, Biotechnology Adv. 27, 76-83 (2009) DOI: 10.1016/j.biotechadv.2008.09.002

55. I. Feng, J. Wu, G.Q. Chen, F.Z. Cui, T.N. Kim, J.O. Kim, J. Biomed. Res. 52, 662-668 (2000) D0I: 10.1002/1097-4636(20001215)52:4<662::aidjbm10>3.0.co;2-3

56. Sondi, B. Salopek-Sondi, J. Colloid. Interface. 275, 177-182 (2007) DOI: 10.1016/j.jcis.2004.02.012

57. Tang, J. Zheng, Adv. Healthc. Mater. 7, e1701503 (2018) DOI: 10.1002/adhm.201701503

58. Chopra, J. Antimicrob. Chemother. 59, 587-590 (2007) DOI: 10.1093/jac/dkm006

59. Fabrega, J.C. Renshaw, J.R. Lead, Environ. Sci. Technol. 49, 9004-9009 (2009) DOI: 10.1021/es901706j

60. Hartmann, M. Mühling, A. Wolf, F. Mariana, T. Maskow, F. Mertens, T.R. Neu, J. Lerchner, J. Microbiol. Methods. 95, 129-137 (2013) DOI: 10.1016/j.mimet.2013.08.003

61. Kalimuthu Kalishwaralal, Selvaraj BarathManiKanth, Sureshbabu Ram Kumar Pandian, Deepak Venkataraman, S. Gurunathan, Colloids and Surfaces B: Biointerfaces. 79, 340-344 (2010) DOI: 1016/j.colsurfb.2010.04.014 
62. A. Ansari, H.M. Khan, A.A. Khan, S.S. Cameotra, M.A. Alzohairy, Indian J. Med. Microbiol. 33, 101-109 (2015) DOI: 10.4103/02550857.148402

63. J. Park, S. Park, J. Roh, S. Kim, K. Choi, J. Yi, J. Kim, J. Yoon, J. Industr. Eng. Chem. 19, 614-619 (2013) DOI: 10.1016/j.jiec.2012.09.013

64. Martinez-Gutierrez, L. Boegli, A. Agostinho, E.M. Sanchez, H.Bach, F. Ruiz, G. James, Biofouling. 29, $651-660$ (2013) DOI: $10.1080 / 08927014.2013 .794225$

65. Bjarnsholt, K. Kirketerp-Møller, S. Kristiansen, R. Phipps, A.K. Nielsen, P.Ø. Jensen, N. Høiby, M. Givskov, APMIS. 115, $921-928$ (2007) DOI: 10.1111/j.1600-0463.2007.apm_646.x

66. S. Islam, C. Larimer, A. Ojha, I. Nettleship, Mater. Sci. Eng. C.33, 4575-4581 (2013) DOI: 10.1016/j.msec.2013.07.013

67. Gorbunova, L. Lemkina, J. Biomed. Mater. Res. A. 104, 630-638 (2016) DOI: 10.1002/jbm.a.35596

68. A. Radzig, V.A. Nadtochenko, O.A. Koksharova, J. Kiwi, V.A. Lipasova, I.A. Khmel, Colloids and Surfaces B: Biointerfaces. 102, 300-306 (2013) DOI: 10.1016/j.colsurfb.2012.07.039

69. Albert, P. Feiertag, G. Hayn, R. Saf, H. Hönig, Biomacromolecules. 4, 1811-1813 (2003) DOI: 10.1021/bm0342180

70. Broxton, P.M. Woodcock, F. Heatley, P. Gilbert, J. Appl. Bacter. 57, 115-124 (1984) DOI: 10.1111/j.1365-2672.1984.tb02363.x

71. R. Hoffman, D.A. D’Argenio, M.J. MacCoss, Z. Zhang, R.A. Jones, S.I. Miller, Nature. 436, 1171-1175 (2005) DOI: 10.1038/nature03912

72. Wu, X. Li, M. Gunawardana, K. Maguire, D. Guerrero-Given, Ch. Schaudinn, Ch. Wang, M.M. Baum, P. Webster, PLOS ONE. 9, e99204 (2014) DOI: 10.1371/journal.pone.0099204

73. Nikaido, M. Vaara, Microbiology Review. 49, 1-32 (1985) PMID: 2580220

74. Gilbert, D. Pemberton, D.E. Wilkinson, J. Appl. Bacter. 69, 585-592 (1990) DOI: 10.1111/j.1365-2672.1990.tb01552.x

75. Rahman, M.Z. Ahmad, I. Kazmi, S. Akhter, M. Afzal, G. Gupta, F.J. Ahmed, F. Anwar, Expert Opin. Drug Deliv. 9, $367-381$ (2012) D0I: $10.1517 / 17425247.2012 .668522$

\section{Figures}



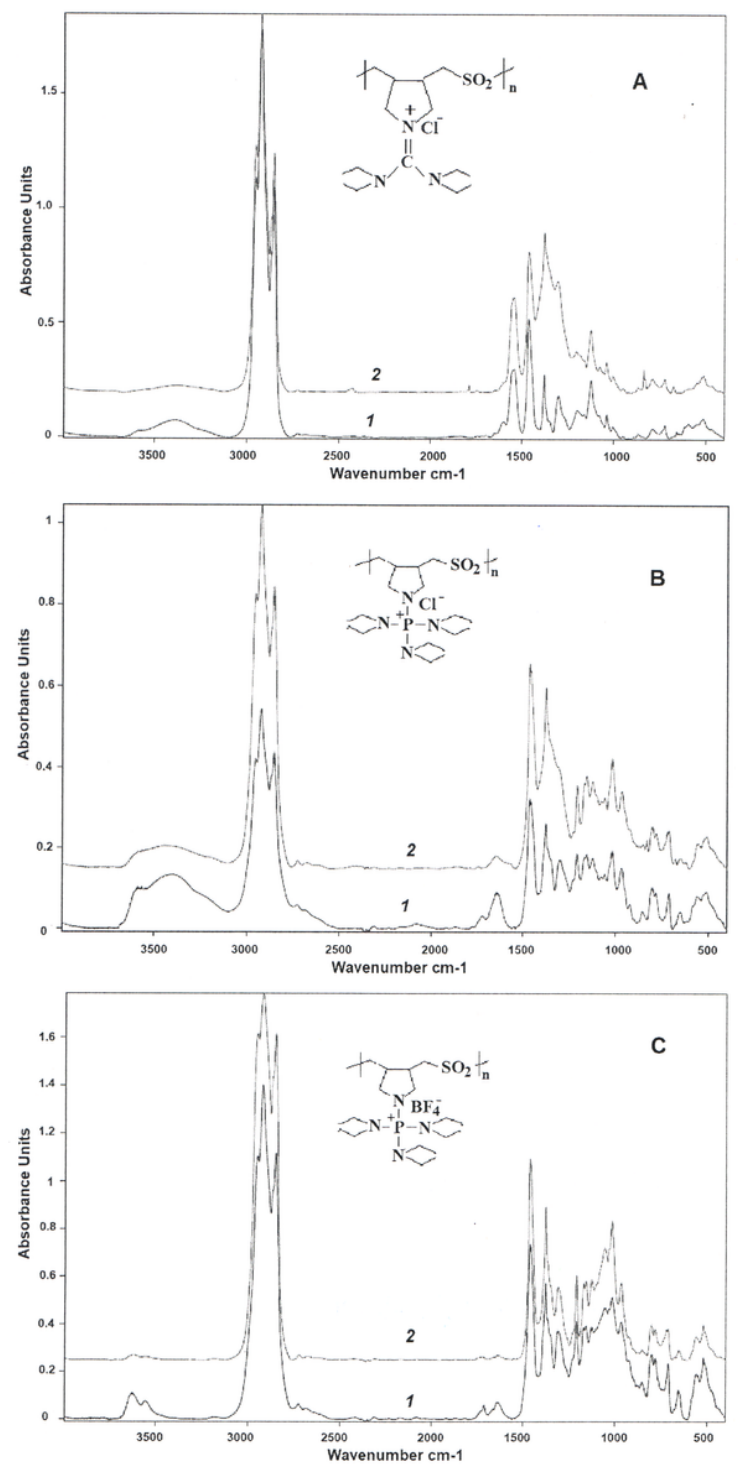

Figure 1

IR spectra of polysulfones (1) and their nanocomposites (2) in vaseline oil: A - poly(AGC-SO2), B - poly(DAAP-Cl-SO2), C - poly(DAAP-BF4-SO2). 


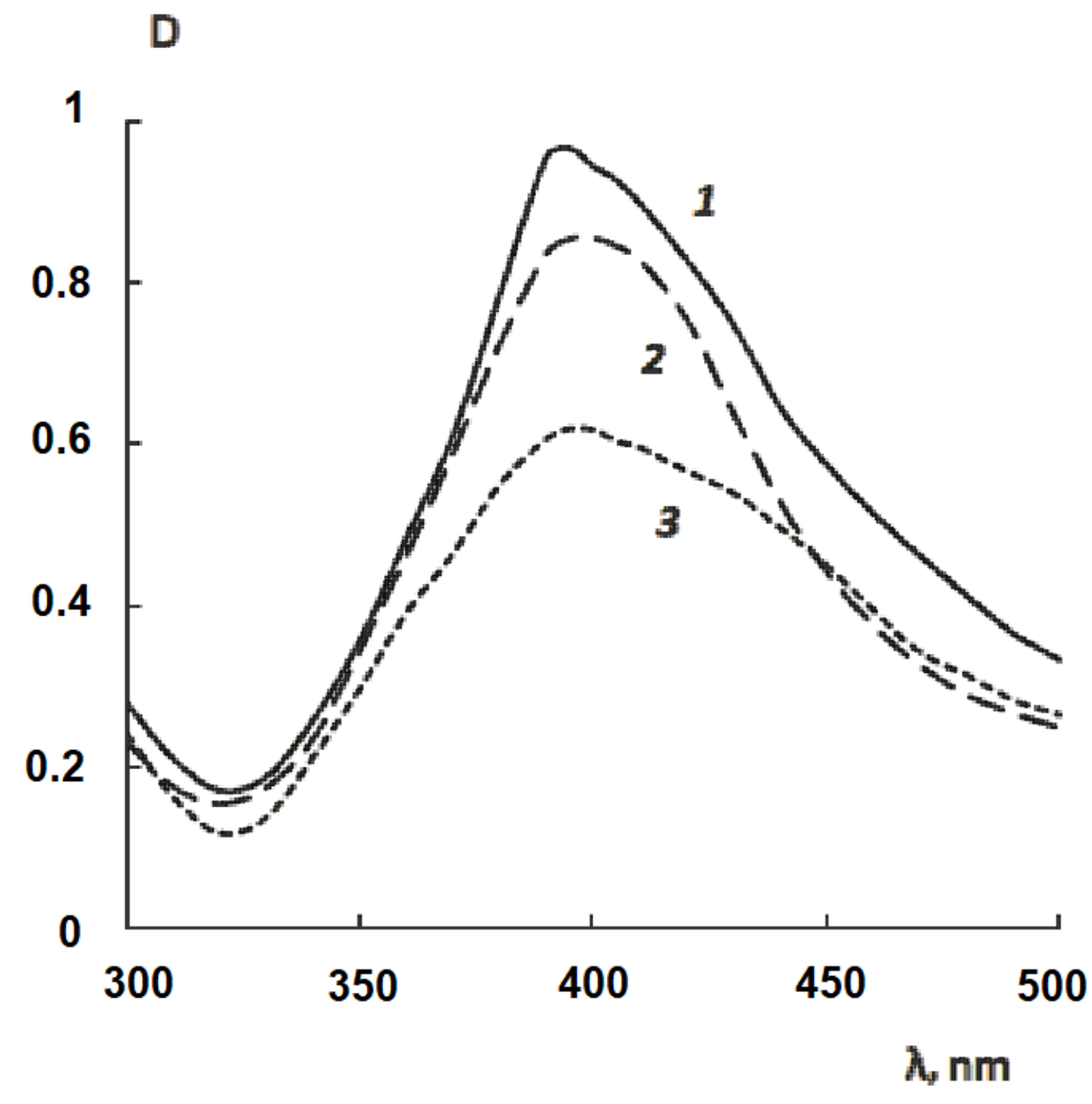

Figure 2

UV extinction spectra of nanocomposite solutions: 1 - poly(AGC-SO2), aqueous solution, C $=1.3 \cdot 10-4 \mathrm{~mol} / \mathrm{l} ; 2-$ poly(DAAP-Cl-SO2), aqueous solution, $\mathrm{C}=10-4 \mathrm{~mol} / \mathrm{l} ; 3-$ poly(DAAP-BF4-SO2), alcoholic solution, $\mathrm{C}=1.2 \cdot 10-4 \mathrm{~mol} / \mathrm{l}$. 


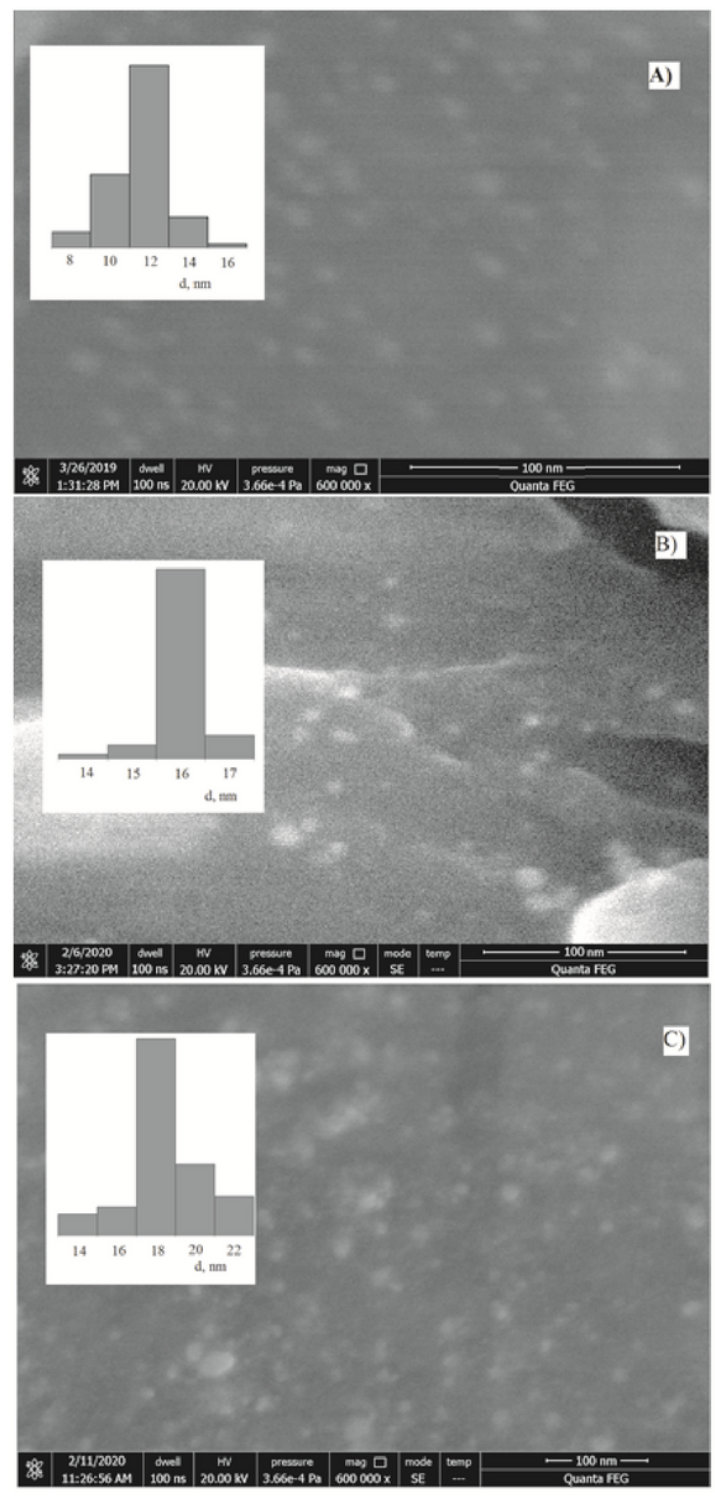

Figure 3

SEM images of silver nanoparticles in poly(AGC-SO2) (A), poly(DAAP-Cl-SO2) (B) and poly(DAAP-BF4-SO2) (C) and their particle size distribution histograms. 

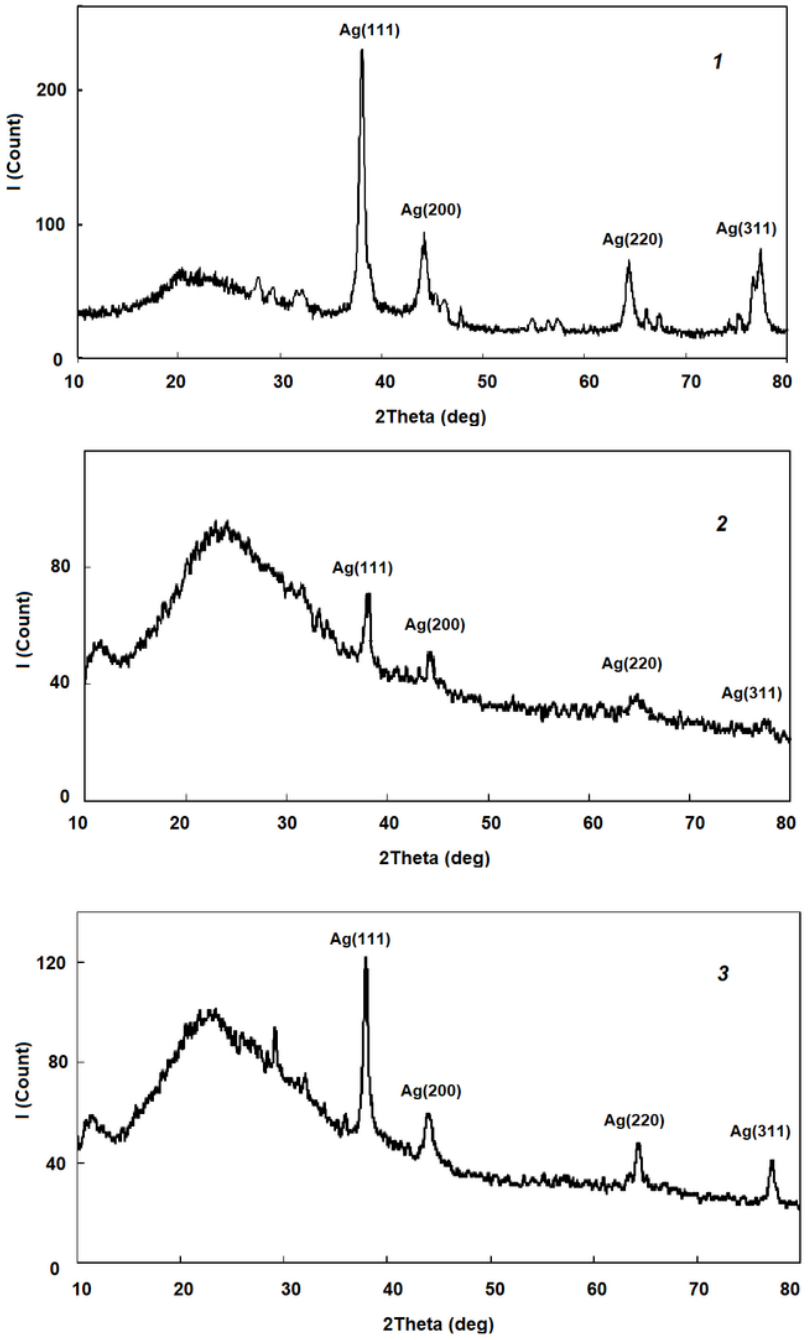

Figure 4

XRD patterns of AgNCs: 1 - poly(AGC-SO2), 2 - poly(DAAP-Cl-SO2), 3- poly(DAAP-BF4-SO2). 

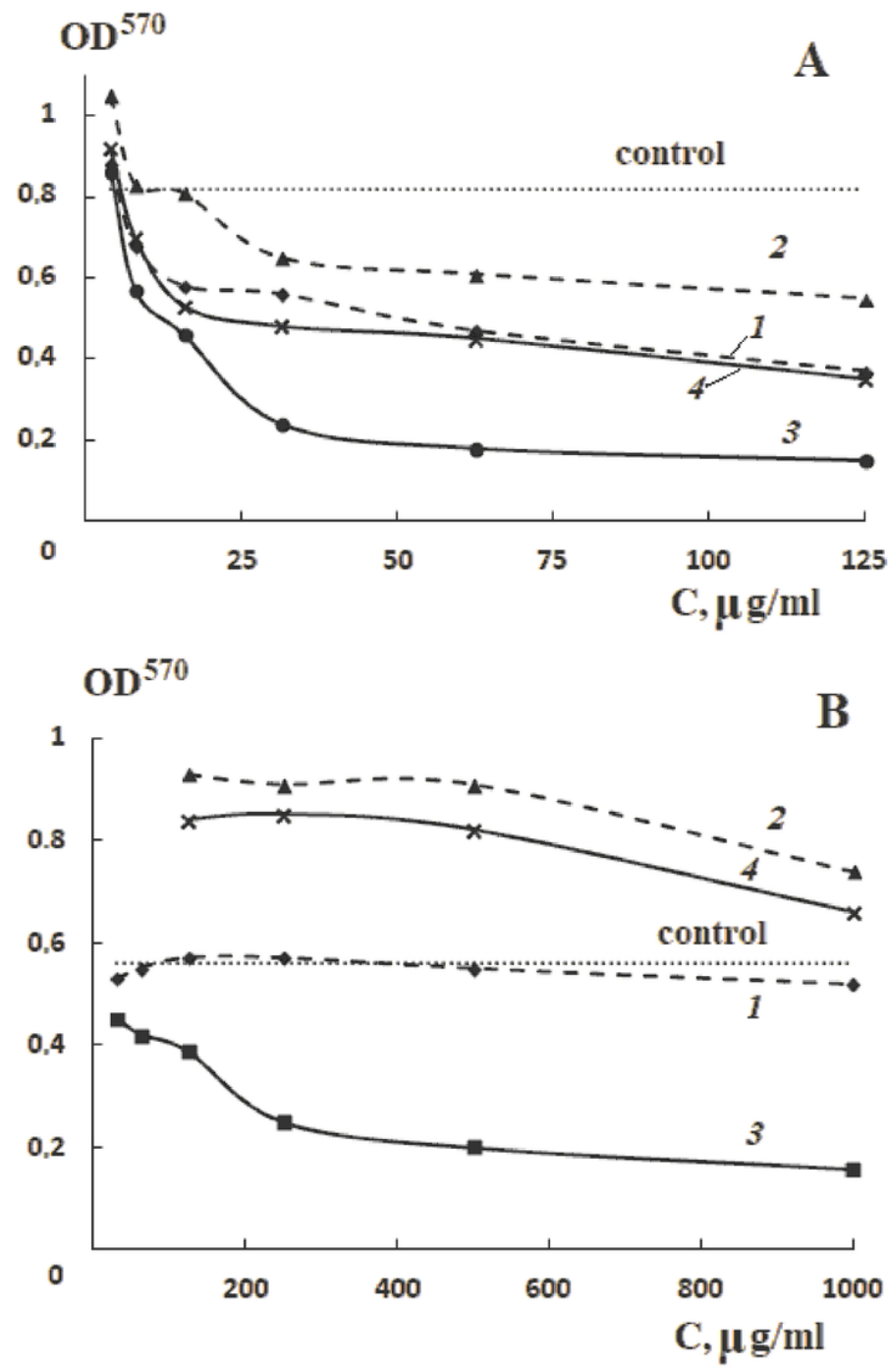

Figure 5

Influence of copolymers and AgNCs on formation of S. epidermidis 33 (A) and E. coli (B) biofilms. 1 - poly(AGC-SO2), 2 - poly(DAAP-Cl-SO2), 3 - nanocomposite on the basis of poly(AGC-SO2), 4 - nanocomposite on the basis of poly(DAAP-Cl-SO2). 

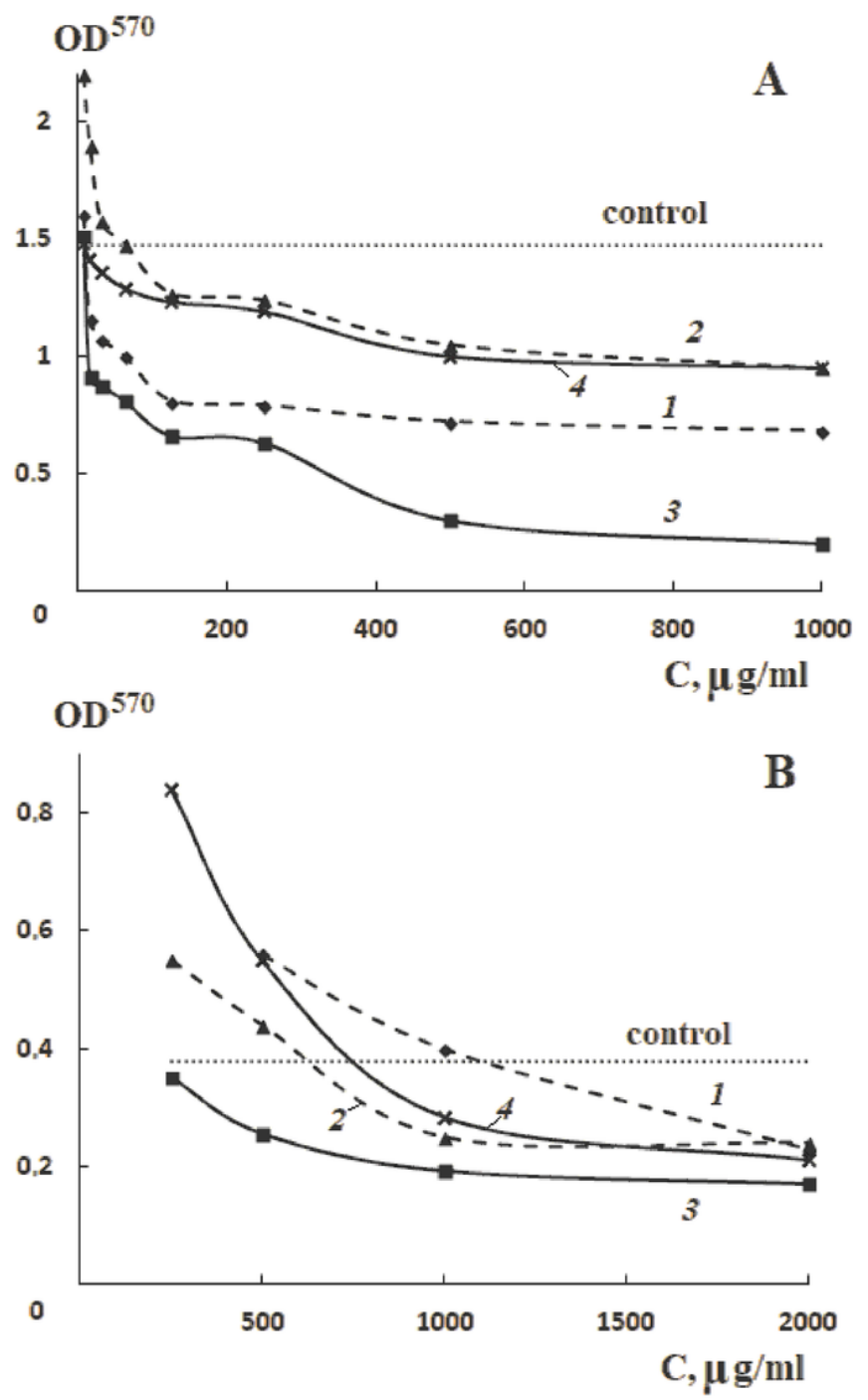

Figure 6

Influence of copolymers and AgNCs on the developed S. epidermidis 33 (A) and E. coli (B) biofilms. 1 - poly(AGC-SO2), 2 - poly(DAAP-Cl-SO2), 3 - nanocomposite on the basis of poly(AGC-SO2), 4 - nanocomposite on the basis of poly(DAAP-Cl-SO2).

\section{Supplementary Files}

This is a list of supplementary files associated with this preprint. Click to download.

- Graphicalabstract.tif

- Supplementary.doc 